\title{
Erratum
}

\author{
Research Article
}

\section{Using diatoms to assess geographical patterns of change in high-altitude European lakes from pre-industrial times to the present day}

\author{
Gina Clarke, Martin Kernan, Aldo Marchetto, Sanna Sorvari and Jordi Catalan
}

This is the corrected version of the Acknowledgments and some references of the above mentioned article that appeared electronically Online First on April 1, 2005 (this issue, pp. 224-236).

\section{Acknowledgments}

This research is part of the EMERGE Framework 5 project, supported by the European Union. Diatom data contributions were made from Simona Musazzi, Mauro Veronesi, Joachim Hürlimann, Monica Tolotti, RainoLars Albert, Elena Štefková, Joan Garcia, Sergi Pla, Nadja Ognyanova, Elena Voinea and Milijan Šiško. The authors would like to thank Viv Jones and Andrew Henderson for their comments and suggestions on the manuscript and Gavin Simpson for his help with the chord distance analyses.

\section{References}

Agbeti, M. D., J. C. Kingston, J. P. Smol and C. Watters, 1997. Comparison of phytoplankton succession in two lakes of different mixing regimes. Arch. Hydrobiol. 140: 37-69.

Anderson, N. J., R. W. Battarbee, P. G. Appleby, A. C. Stevenson, F. Oldfield, J. Darley and G. Glover, 1986. Palaeolimnological evidence for the acidification of Loch Fleet. Palaeoecological Research Unit, Department of Geography, University College London. Research Paper No. 17: 1-70.

Battarbee, R. W., 1984. Diatom analysis and the acidification of lakes. Philosophical Transactions of the Royal Society of London B 305: 451-457.

Battarbee, R. W, S. Juggins, F. Gasse, N. J. Anderson, H. Bennion, N. G. Cameron, D. B. Ryves, C. Pailles, F. Chalie and R. Telford, 2001. European Diatom Database (EDDI) An information system for palaeoenvironmental reconstruction 81: 1-94. London, ECRC Research Report.

Published on Web: September 21, 2005
Birks, H. J. B., J. M. Line, S. Juggins, A. C. Stevenson and C. J. F. ter Braak, 1990a. Diatoms and pH reconstruction. Philosophical Transactions of the Royal Society of London B 327: 263-278.

Bradbury, J. P. 1988. A climatic-limnologic model of diatom succession for paleolimnological interpretation of varved sediments at Elk Lake, Minnesota. Journal of Paleolimnology 1: 115-131.

Camburn, K. E. and D. F. Charles, 2000. Diatoms of Low-Alkalinity Lakes. The Academy of Natural Sciences of Philadelphia, Philadelphia.

Cameron, N. G., H. J. B. Birks, V. J. Jones, F. Berge, J. Catalan, R. J. Flower, J. Garcia, B. Kawecka, K. A. Koinig, A. Marchetto, P. Sánchez-Castillo, R. Schmidt, M. Šiško, E. Solovieva, E. Štefková and M. Toro, 1999. Surface-sediment and epilithic diatom $\mathrm{pH}$ calibration sets for remote European mountain lakes (AL: PE project) and their comparison with the Surface Waters Acidification Programme (SWAP) calibration set. Journal of Paleolimnology 22: 291-317.

Catalan, J., L. Camarero, E. Gacia, E. Ballesteros, M. Felip, 1994. Nitrogen in the Pyrenean lakes (Spain). Hydrobiologia 274: $17-27$.

Catalan, J., S. Pla, M. Rieradevall, M. Felip, M. Ventura, T. Buchaca, L. Camarero, A. Brancelj, P. G. Appleby, A. Grytnes, A. Agustí-Panareda and R. Thompson, 2002. Lake Redó ecosystem response to an increasing warming in the Pyrenees during the twentieth century. Journal of Paleolimnology 28: $129-145$.

Cumming, B. F., J. P. Smol, J. C. Kingston, D. F. Charles, H. J. B. Birks, K. E. Camburn, S. S. Dixit, A. J. Uutala. and A. R. Selle, 1992. How much acidification has occurred in Adirondack Region Lakes (New York, USA) since pre-industrial times? Canadian Journal of Fisheries and Aquatic Sciences 49: 128-141.

Dixit, S. S., A. S. Dixit and J. P. Smol, 1992. Assessment of changes in lake water chemistry in Sudbury area lakes since pre-industrial times. Canadian Journal of Fisheries and Aquatic Sciences 49: (Supplement 1), 8-16. 
Dixit, S. S., J. P. Smol, D. F. Charles, R. M. Hughes, S. G. Paulsen and G. B. Collins, 1999. Assessing water quality changes in the lakes of the north-eastern United States using sediment diatoms. Canadian Journal of Fisheries and Aquatic Sciences 56: $131-152$.

Douglas, M. S. V., J. P. Smol and W. Blake Jr, 1994. Marked post18th century environmental change in high-Arctic ecosystems. Science 266: 416-419.

Goudsmit, G. H., G. Lemcke, D. M. Livingstone, A. F. Lotter, B. Müller and M. Sturm, 2000. Hagelseewli: A fascinating high mountain lake- suitable for palaeoclimate studies? Verh. Internat. Verein. Limnol, 27: 1013-1022.

Hall, R. I. and J. P. Smol, 1992. A weighted averaging regression and calibration model for inferring total phosphorus concentration from diatoms in British Columbia. Freshwater Biology 27: 417-434.

Koinig, K. A., C. Kamenik, R. Schmidt, A. Agustí-Panareda, P. Appleby, A. Lami, M. Prazakova, N. Rose, Ø. A. Schnell, R. Tessadri, R. Thompson and R. Psenner, 2002. Environmental changes in an alpine lake (Gossenköllesee, Austria) over the last two centuries - the influence of air temperature on biological parameters. Journal of Paleolimnology 28: 147-160.

Livingstone, D. M., A. F. Lotter and I. R. Walker, 1999. The decrease in summer surface water temperatures with altitude in Swiss Alpine lakes: a comparison with air temperature lapse rates. Arctic, Antarctic and Alpine Research 31: 341-352.

Lotter, A. F., H. J. B. Birks, W. Hofmann and A. Marchetto, 1997. Modern diatoms, cladocera, chironomid, and chrysophyte cyst assemblages as quantitative indicators for the reconstruction of past environmental conditions in the Alps I. Climate. Journal of Paleolimnology 18: 395-420.

Lotter, A. F, H. J. B. Birks, W. Hofmann and A. Marchetto, 1998. Modern diatoms, cladocera, chironomid, and chrysophyte cyst assemblages as quantitative indicators for the reconstruction of past environmental conditions in the Alps II. Nutrients. Journal of Paleolimnology 19: 443-463.

Magnuson, J. J., D. M. Robertson, B. J. Benson, R. H. Wynne, D. M. Livingstone, T. Arai, R. A. Assel, R. G. Barry, V. Card, E. Kuusisto, N. G. Granin, T. D. Prowse, K. M. Stewart and V. S. Vuglinski, 2000. Historical trends in lake and river ice-cover in the Northern Hemisphere. Science 289: 1743-1746.
Marchetto, A and R. Bettinetti, 1995. Reconstruction of the phosphorus history of two deep, subalpine Italian lakes from sedimentary diatoms, compared with long term chemical measurements. Mem. Ist. Ital. Idrobiol. 53: 27-38

Nickus, U., H. Thies, M. Kuhn and R. Psenner, 1998. The snow cover at a headwater site in the Tyrolean Alps: seasonal and local variability of atmospheric trace substances in the snow pack. HeadWater '98: Hydrology, Water Resources and Ecology of Mountain Areas. (Tappeiner, U, F. V. Ruffini and M. Fumai eds.), 39-42. IAHS Publication.

R Development Core Team, 2003. R: A language and environment for statistical computing. R Foundation for Statistical Computing, Vienna Austria, Unpublished Manual.

Renberg, I., 1991. The HON-Kajak sediment corer. Journal of Paleolimnology 6: 167-170.

Rose, N., 2001. Fly Ash Particles, 319-349. In Last, W. M. and J. P. Smol, (eds.), Tracking Environmental Change Using Lake Sediments. Volume 2: Physical and Geochemical Methods. Kluwer Academic Publishers, Dordrecht.

Schmidt, R., K. A. Koinig, R. Thompson and C. Kamenik, 2002. A multi proxy core study of the last 7000 years of climate and alpine land-use impacts on an Austrian mountain lake (Unterer Landschitzsee, Niedere Tauern). Palaeogeography, Palaeoclimatology, Palaeoecology 187: 101-120.

Sorvari, S. and A. Korhola, 1998. Recent diatom assemblage changes in subarctic Lake Saanajärvi, NW Finnish Lapland, and their palaeoenvironmental implications. Journal of Paleolimnology 20: 205-215.

Šporka, F., E. Štefková, P. Bitušik, R. Thompson, A. AgustíPanareda, P. G. Appleby, J. A. Grytnes, C. Kamenik, I. Krno, A Lami, N. Rose and N. E. Shilland, 2002. The paleolimnological analysis of sediments from high mountain lake Nižne Terianske pleso in the High Tatras (Slovakia). Journal of Paleolimnology 28: $95-109$.

ter Braak, C. J. F., 1987. Calibration. Data analysis in community and landscape ecology (Jongman, R. H. G, C. J. F. ter Braak and O. R. F. van Tongeran eds.), pp. 78-90. Pudoc Wageningen.

ter Braak, C. J. F. and I. C. Prentice, 1988. A theory of gradient analysis. Advances in Ecological Research 18: 271-317. 